
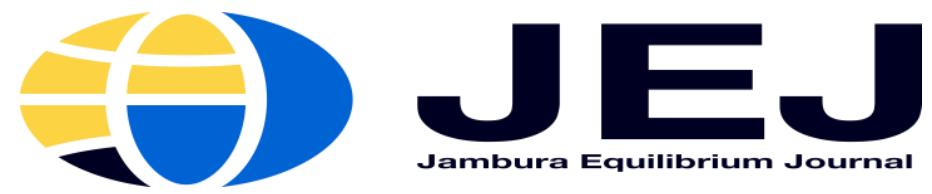

Volume 3. Issue 1. January 2021

P-ISSN 2655-9110

E-ISSN 2656-0445

http://ejurnal.ung.ac.id/index.php/equij

\title{
Convergence Islamic Values as Economic Development
}

Dede Aji Mardani

Sekolah Tinggi Agama Islam Tasikmalaya, Jawa Barat, Indonesia

\begin{abstract}
Tasikmalaya economic growth has been increasing economic growth in the last 10 years. This is influenced by the fulfillment of unlimited human needs.This study aims to analyze the relationship between religious values held by entrepreneurs and economic growth. The method used is descriptive qualitative with an economic anthropology approach. The results show that entrepreneurs who come from various ethnic in Indonesia show that religious teachings really influence the level of their business activities. That business is not only for material purposes only but is further than that as an end day investment. The values of religious sacredness have been inherent in the personality of entrepreneurs such as honesty, frugality, openness and transparency, which are religious values taught when making transactions. These religious values in fact have an impact on increasing the value of sales in their business, with the increase in their business directly driving regional economic growth. income increases, unemployment decreases, local taxes increase. This shows that the work ethic of Muslim entrepreneurs in Tasikmalaya has helped in national economic growth. Finally, the local government can maintain harmony and peace in the economic and political situation of Tasikmalaya so that the climate of economic growth and the prosperity of the people can be maintained.
\end{abstract}

Keywords: Islamic Work Ethic; Islamic Values; Moslem Entrepreneur

\section{INTRODUCTION}

Muslim

entrepreneurs

in conducting their trade are inseparable from values, ethos as the basis that drives and underlies it (Yulius, 2018). The strength of the work ethic, enthusiasm, attitude and cooperation of employees have become the driving force of the business. In fact and micro-macro data, the impact of the work ethic of Muslim entrepreneurs can be seen from the trade volume in Tasikmalaya which has grown rapidly from year to year, as can be seen clearly at the level of GRDP (Gross Regional Domestic Income) during the last 10 years released by BPS (BPS
Kota Tasikmalaya, 2020a) The following data is presented by PDBR Tasikmalaya from 2010-2019.

Table 1. PDRB Tasikmalaya, 2010-2019

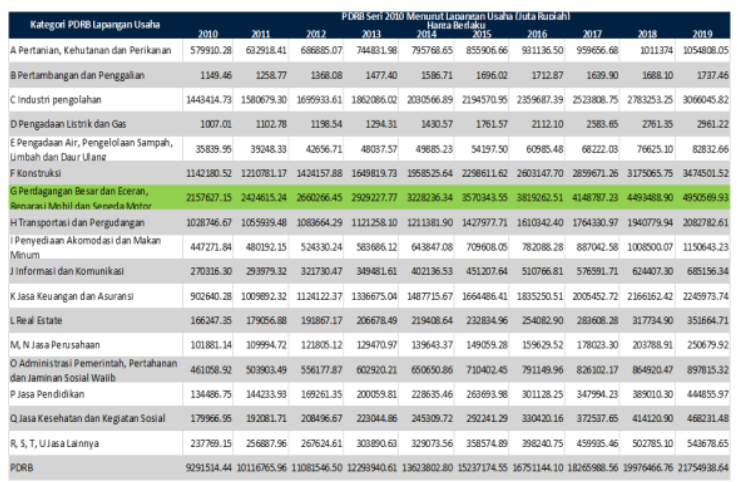


In the period 2010 - 2019, the PDRB value of Tasikmalaya in the field of business experienced a successive increase of 2,157 million rupiah in (2010); in the amount of 2,425 million years (2011); or an increase of $8 \% ; 2,660$ million in the year (2012); 2,930 million in the year (2013); or an increase of $9 \%$; 3,229 million (2014); 3,570 million years (2015); increased by $10 \%$; 3,819 million years (2016); 4,149 million (2017); or an increase of $10.8 \%$; 4,493 million (2018); and 4.951 million and years (2019); increased by $11 \%$. Overall, the data shows an average increase of $10 \%$ ((BPS Kota Tasikmalaya, 2020b).

The PDRB movement cannot be separated from the work ethic of the role of traders in Tasikmalaya with the composition of traders from various components of society who choose to make a living in this city. In addition, entrepreneurs apply one of the commercial practices that are absorbed from religious values such as honesty. They apply this honest nature in transactions, among others, by identifying and separating good quality, prices that are commensurate with quality and clear information regarding the goods they sell (Mardani, 2019) which will have an impact on other buyers / consumers who are satisfied with the services provided by Muslim entrepreneurs Indirectly they have carried out the concept of trade using the Islamic economic system .(Hendryadi, 2018; Juliyani, 2016)

Explanations that are verbal, numeric, labeled as well as separating which quality is number one and quality number two directly satisfy consumers or customers because entrepreneurs apply a concept of honesty and transparency as well as clarity of goods and prices including specifications (Hamzah \& Hafid, 2014) Tasikmalaya Muslim entrepreneurs have long been doing business by expanding their business even though they have to compete, with traders from various ethnicities, such as Sundanese, Padang, Javanese and Chinese who have controlled this area for more than half a century (Djakfar, n.d.)

From the research that has been done, that these traders come from various provinces of West Java and outside West Java who open their business branches in the City of Tasikmalaya. Traders who originate from the City of Tasikmalaya actually open branches and become entrepreneurs in other cities such as in Jakarta, Bandung and Pangandaran, the distribution pattern of Tasikmalaya City entrepreneurs has spread to various cities in Indonesia (Mudzakkir, 2017a).

The second social fact is the historical aspect, where originally the city Tasikmalaya, in the HZ Zainal Mustofa route along the way, belonged to Haji Bakri until 1960 (interview with $\mathrm{H}$ Bakri's grandson). Recently, the conditions and positions of the City have all been controlled by various ethnic groups who dominate trade in Tasikmalaya City, so that the existence of Muslim entrepreneurs has been increasingly marginalized (Mudzakkir, 2017b).

According to historical witnesses, Muhajir, originally all the shops that were lined up in the area of Jln $\mathrm{KH}$ Zainal Mustofa belonged to a Muslim entrepreneur, Haj Bakri. However, after the 1960s, many of the shops and buildings were sold to other parties because they were pressed by various needs, as well as as inheritance (interview results).

Researchers conducting observations in the field found that there is hope from the local Muslim community and traders to repeat the history of the desire to control the economic sector by Muslims (Muhajir Salam, 2017). In the picture, you can see how the atmosphere of the City of Tasikmalaya in the center of the City was selling its wares as shown below: 


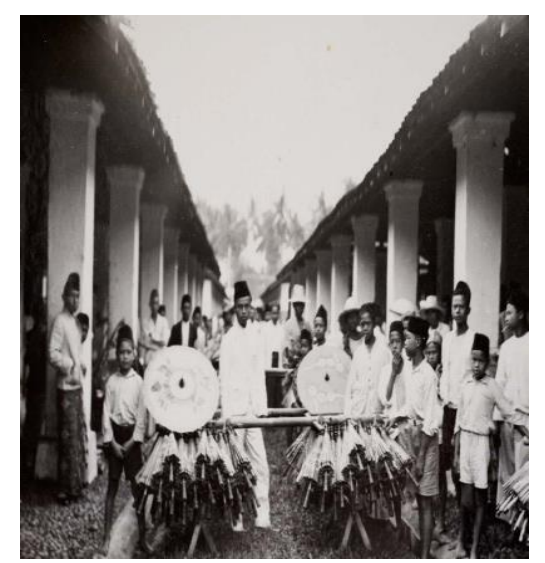

Figure 1. The market location is on

\section{Jalan Dr. Sukarjo, Tasikmalaya City}

Previously, Tasikmalaya City was known as a Batik-producing City under the auspices of Mitra Batik in 1930, the formation of this cooperative was a form of consolidation and one form of uniting Muslim entrepreneurs (M. Salam, 2017). Apart from being known as a batik producing Tasikmalaya is known as a region that produces handicrafts that have long been marketed to European countries.

The third fact is the enactment of a regional regulation on values by the government of the city of Tasikmalaya, which in one of its points is for the residents of Tasikmalaya to always maintain morals, maintain harmony between religious followers, including in trading activities using Islamic economic principles and instruments (Kirchmaier et al., 2018b). Of course the working spirit of these Muslim entrepreneurs is inseparable from their work ethic, level of religiosity (diversity) and Islamic values that they have embraced so far obtained from the holy book through Tasikmalaya scholars (Amaliah et al., 2015).

The values of honesty, trustworthiness, calculation, frugality, charity are some of the factors that motivate these Muslim traders to make transactions (Bruce, 2013, p. 220; Michele Dillon, 1959, p. 96). The Islamic values that have been imprinted in every behavior of these traders are influenced by religion, social environment, customs, and completely integrated norms through the process of assimilation and acculturation (Gordon, 1964; Suratman, 2019). In theory, Gordon divides the levels of assimilation into the process: 1) structural similation; 2) marital assimilation; 3) identification assimilation; 4) assimilation of acceptance of attitude; 5) assimilation of acceptance of behavior. These five processes work together continuously in a pluralistic society.

This assimilation process is formed which will create a community and if this occurs the community will create a market or sale and purchase transaction. Even so, there have been many studies that link the work ethic of Muslim entrepreneurs with the values of Islamic teachings (Beekun \& Badawi, 2005)However, in general, research between work ethics using IWE has not been done much for Muslim entrepreneurs, especially in the context of Tasikmalaya.

Researchers see the City of Tasikmalaya as a city that is quite unique, and develops seen from the synergy of the economy, the thick religious values (religiosity) of its people as well as a pocket or center that gives birth to many Muslim entrepreneurs who have modern and traditional views, and migrants as creditors and Toilets for City and Regency levels (Janwari, nd, p. 54; Wasisto Raharjo Jati, 2018) in the East Priangan region and have actually spread to remote parts of the country. In addition, Tasikmalaya has become business centers, a place for representatives of government agencies in the financial and monetary sector (Bank Indonesia, OJK), as well as dozens of banks (Commercial Banks and Sharia Banks) and the Non-Bank Financial Industry (IKNB).

The researcher saw that KH Zainal Mustofa street, which is located from the 
Grand Mosque of Tasikmalaya to the first intersection of Jalan Panyerutan, who were known and considered successful by businessmen. With the result of data observation of all traders as many as 87 with shops owned by Muslim entrepreneurs as many as 10 shops. The reason is that researchers researched the area of Jln $\mathrm{KH}$ Zainal Mustofa, that this area has become the centre of an economy, a shopping center and a developed trade compared to other cities in East Priangan.

Even so, there are still many large Muslim businessmen scattered in the outskirts of the city who are no less successful in terms of the number of assets and the number of business units they own. Previously, the traders along KH Zainal Mustofa street were dominated by Muslim businessmen, but now the situation is reversed and shrinking, on the contrary, Muslim entrepreneurs have become less / less and dominated by Chinese entrepreneurs.

Known as a city with a fast level of trade in the East Priangan area (BPS Kota Tasikmalaya, 2020b) Tasikmalaya is known as the City of Santri because it has more than 539 Islamic boarding schools in the district and 91 Islamic boarding schools in the Tasikmalaya area (Nusantara, 2019)And the existence of this pesantren cannot be separated from the history of the field (historical groundeed), from the Dutch era to the present (Permani, 2011).

The struggles of the santri both in liberating Indonesia and doing entrepreneurship in Tasikmalaya (Nadjib, 2013) from the Dutch to the Japanese have been painted and immortalized in inscriptions and legacies of the struggle for the movement. The naming of roads, sites or buildings was based on the names of freedom fighters when they took physical colonialism from the Dutch and Japanese as a form of appreciation and respect for the role of the heroes of Tasikmalaya
(Kirchmaier et al., 2018a) Heroicity of fighters, not only in this city but has been described as cities and regions in Indonesia.

Historical formulation before the Dutch entered Tasikmalaya, in essence can be viewed from the perspective of Tasikmalaya history. At first it came from the work of Galunggung (Muhajir Salam, 2015) which then moved to the Mataram kingdom until the Dutch colonial period. At that time, Muslim businessmen had dominated trade dari sektor perkebunan, perhutanan dan Tekstil (Batik) (Mudzakkir, 2017b, p. 56). The characteristics of Tasik traders have been proven to be a tradition until now which has spread to various corners of the country. Islamic values that shape the mindset and actions of Muslim entrepreneurs result in dynamics in doing business (Gümüsay, 2015).

Along with a strong foundation regarding the socioculture Tasikmalaya people which bears the name of the city of students, it is not surprising that the City government issued a regional regulation on values which was the answer to the response of the Ulama and Tasikmalaya leaders at that time to encourage the implementation of Islamic law. The Perda on the value system of the City of Tasikmalaya provides a clearer legal umbrella for Muslims in particular to carry out all their activities in accordance with Islamic law and have an economy with a sharia economy (Peraturan Daerah Kota Tasikmalaya Nomor: 12 Tentang Pembangunan Tata Nilai Kehidupan Kemasyarakayan Yang Berlandaskan Pada Ajaran Agama Islam Dan Norma Norma Sosial Masyarakat Kota Tasikmalaya, 2009).

In economic development, religious values, ethics, morality have been seen as important foundations in the progress of the nation and state. These two things cannot be taken lightly and are judged from the normative side alone, but are a positive 
outcome of the values of faith contained in every individual trader (Castellani, 2019).

\section{LITERATURE REVIEW}

The concept of Islamic work ethics or Islamic Work Ethic (IWE) itself was put forward by Abbas $\mathbf{J}$ Ali in 2008, to be precise in Indiana, United States. Research conducted on 150 students from the Arab region, which concluded that there is a positive and significant correlation between IWE and their work. He explained that working in Islam lies at the core of faith and is considered an integral part of life (Ali \& Al-Owaihan, 2008). Furthermore, in Muslim society, the words of the prophet Muhammad and the text of the Koran are an integral part of the dynamic that must be adhered to in all human life, including in the fields of economy and trade. Therefore, using Al-Quran and Sunnah sources is a must in every business activity, while IWE itself is a derivative of Islamic values (Rokhman, 2010).

\section{METHODOLOGY}

The research approach used is qualitative, where the object of the study in this study is Muslim entrepreneurs who are in the city of Tasikmalaya with various business activities. Qualitative research is used because the object of research, namely humans as social beings, has a tendency to change every time and is dynamic (verstehen), therefore it is necessary to research in-depth by following life patterns, entering into the object of research and being involved in it (Kaelan, 2010). With qualitative research, it will reveal the dimensions of various activities in various perspectives, the mode of operation carried out, the motivation of the Muslim entrepreneurs in carrying out their trade.

\section{RESULTS}

\section{Moslem, Entrepreneurs, and Economic Growth in Tasikmalaya}

Boarding Schols is an institution that provides educational services to deepen religious knowledge and other general sciences (modern pesantren). It is also an institution that is quite old in Indonesia. Many pesantren have undergone a transformation in the fields of curriculum, services, learning methods up to the output of the students, such as entrepreneurship, which is oriented towards being santri and entrepreneur. Islamic boarding schools by combining technology, agribusiness, plantations, vocational schools and others (Krisdiyanto et al., 2019, p. 11).

The term modern pesantren was born from the establishment of the Darusalam Gontor boarding school, Ponorogo which combines Islamic learning with general education and provides facilities in the form of individual lodgings, rooms, mattresses, beds, and wardrobes (Fahham, 2013). The modern Islamic boarding school model has been the prima donna to this day. It can be seen from the data contained in the Ministry of Religion which released the number of Islamic boarding schools in Indonesia as many as 26,971 with $4,173,502$ students, while for West Java there were 8,410 with 718,167 students and for Tasikmalaya district as many as 1,318 while for Tasikmalaya here were 206 with the number of students 12,501 mukim and 9,780 non-resident students (Kementerian Agama, 2020).

Kyai has been running a massive communication built based on patterns of teaching and learning. The teaching pattern between kyai and santri continues on how to learn and its continuation in spreading the teachings of Islam. Apart from the large number of Islamic boarding schools and students living in Tasikmalaya, the designation of Tasikmalaya as the City of Santri is also due to the high religious, 
cultural, ethical and historical values inherent in the identity of the City of Tasikmalaya, especially after the issuance of Perda No.7 of 2014 concerning Values The Religious Life of Tasikmalaya Community (Aryani, 2015).

The relationship between the students and the kyai has a very close relationship when the kyai gives a pattern of leadership to his students. This means that the kyai gives instructions on how someday the students will become the successor in their pesantren either in their area or outside their area when they migrate. In the process of delivering teaching and learning material, the kyai cannot be separated from the holy book guidelines. The values contained in the AlQuran are then transformed into every behavior that starts during routine recitation or specifically in each study. These skills are continuously honed so that later when the students return to their respective regions they can practice what the kyai has taught at the Islamic boarding school (Calder, 2019).

The impact of the polarization between kyai, santri and the community is contagious to the traders in Tasikmalaya, who are predominantly Muslim. Of course, they are often found about the ethics of trading, socializing, or more broadly regarding the joints of life. The role of pesantren, religious leaders and kyai is very strong in shaping the identity of the people of Tasikmalaya. Muslim businessmen who frequently attend various recitations or routine studies receive doctrines and recommendations conveyed by religious leaders from the holy book regarding all dimensions of life.

In this study, traders and entrepreneurs get recitation material such as the features of a businessman or trader. As from history how the preachers exemplify the apostle who was successful as a merchant. The main characteristic possessed by an apostle is having an honest spirit, as the basic capital for investors who entrust their merchandise to the apostle (Amstrong, 2006).

Muhammad's honest nature attracted a wealthy Qurasy widow, so she was attracted to marry him as her husband. This honest nature also made the entire city of Mecca believe in Muhammad's honesty. This story begins when he was entrusted with goods by a merchant, but after three days the person who left the goods did not come while the apostle faithfully waited for three days. This is what makes the inhabitants of Mecca claim that Muhammad was an honest or trustworthy person (Yulianty \& Octaviani, 2014) .

On the other hand, in Weber's thesis, he said that there were religious factors that made the current economic cycle well intertwined due to the capitalization system practiced by followers of the Protetan religion from the Calvinist sect. The entrepreneurial behavior and hard work shown by the Protestant religion considers that hard work is a calling and a necessity to gain spiritual prosperity and become the person who will be elected later on in the last day (Dyck, 2014; Max Weber, 1958).

Modern capitalism, which began in 1980, gave birth to the city of Tasikmalaya as a city filled with businessmen who came from various ethnicities and religions. Seeing this fact will be contrary to the number of Islamic financial institutions which are the basis and financial instruments of the Muslims. In relation to Muslim entrepreneurs in Tasikmalaya, it can be seen that the flow of movements regionally and nationally because Indonesia has a long history in various fields. Like microfinance services, both in rural and urban areas, financial inclusion in Indonesia is currently quite low compared to other developing countries, which causes it to be so low digital domestic services are 
compared to other countries (Cao, 2012; Nashihin, 2014)

One strategy to bridge equal access to Islamic financial institutions is by establishing microfinance institutions (MFIs). MFIs are believed to be an important tool for reaching low-income people. Access to financial services has enabled many low-income families to make significant progress in their own efforts to escape poverty. The government supports the growth of microfinance services through various instruments, such as regulations, subsidies and targeted credit policies. Even in the Perda on values, it is implicit that Tasikmalaya residents use the mualamalah system by using the sharia economy and one of the services for the sharia economy is the LKM, although at this stage the fact that the majority of the population of Tasikmalaya has not yet penetrated the sharia economy(Mardani, 2019).

\section{REFERENCES}

Ali, A. J., \& Al-Owaihan, A. (2008). Islamic Work Ethic: A Critical Review. Cross Cultural Management: An International Journal, 15(1), 5-19. https://doi.org/10.1108/13527600810 848791.

Amaliah, I., Aspiranti, T., \& Purnamasari, P. (2015). The Impact of the Values of Islamic Religiosity to Islamic Job Satisfaction in Tasikmalaya West Java, Indonesia, Industrial Centre. Procedia - Social and Behavioral Sciences, 211(September), 984-991. https://doi.org/10.1016/j.sbspro.2015. 11.131.

Amstrong, K. (2006). Muhammad Prophet for Our Time (A. Baiquni (ed.)). Harpe rCollins Publishers, London.

Aryani, L. (2015). Evaluasi Pelaksanaan Peraturan Daerah Tentang Tata Nilai Kehidupan Masyarakat yang Religius di Kota Tasikmalaya. 2-10.
Beekun, R. I., \& Badawi, J. A. (2005). Balancing ethical responsibility among multiple organizational stakeholders: The Islamic perspective. Journal of Business Ethics, 60(2), 131-145.

https://doi.org/10.1007/s10551-0048204-5.

BPS Kota Tasikmalaya. (2020a). Kecamatan Indihiang DAlam Angka (Badan Pusat Statistik Kota Tasikmalaya (ed.)). BPS Kota Tasikmalaya.

BPS Kota Tasikmalaya. (2020b). Kota Tasikmalaya Dalam Angka 2020. In BPS Kota Tasikmalaya (Ed.), BPS Kota Tasikmalaya. CV. Bachtiar.

Calder, R. (2019). How religio-economic projects succeed and fail: The field dynamics of Islamic finance in the Arab Gulf states and Pakistan, 19752018. Socio-Economic Review, 17(1), 167-193. https://doi.org/10.1093/ser/mwz015.

Cao, S. (2012). Socioeconomic value of religion and the impacts of ideological change in China. Economic Modelling, 29(6), 2621-2626. https://doi.org/10.1016/j.econmod.20 $\underline{12.08 .023 .}$.

Castellani, M. (2019). Does culture matter for the economic performance of countries? An overview of the literature. Journal of Policy Modeling, 41(4), 700-717. https://doi.org/https://doi.org/10.1016 li.jpolmod.2018.06.006.

Djakfar, M. (n.d.). Agama, Etika dan Ekonomi ( Menyikap pemikiran Ekonomi Islam Kontemporer Menyingkap Esensi, Menawarkan Solusi) (A. H. Fathani (ed.); 1st ed.). UIN-Maliki Press.

Dyck, B. (2014). God on management: The world's largest religions, the "theological turn," and organization and management theory and practice. 
In Research in the Sociology of Organizations (Vol. 41). Emerald Group Publishing Limited. https://doi.org/10.1108/S0733558X20140000041010

Gümüsay, A. A. from an I. P. (2015). Entrepreneurship from an Islamic Perspective. Journal of Business Ethics, 130(1), 199-208. https://doi.org/10.1007/s10551-0142223-7

Hamzah, Y., \& Hafid, H. (2014). Etika Bisnis Islami. Kretakupa Print Makassar.

Hendryadi. (2018). Islamic Work Ethics (IWE): konsep dan tinjauan penelitian. Jurnal Riset Manajemen Dan Bisnis (JRMB) Fakultas Ekonomi UNIAT, 3(2), 183-190.

Juliyani, E. (2016). Etika Bisnis Dalam Persepektif Islam. Ummul Qura, VII(1), 63-74.

Kaelan. (2010). Metode Penelitian Agama Kualitatif Interdisipliner (Kaelan (ed.); pertama). Paradigma.

Kementerian Agama. (2020). Statistik Data Pondok Pesantren. Pangkalan Data Pondok Pesantren. https://ditpdpontren.kemenag.go.id/pd $\mathrm{pp} / \mathrm{statistik}$ id $=32$

Kirchmaier, I., Prüfer, J., \& Trautmann, S. T. (2018a). Journal of Economic Behavior and Organization Religion, moral attitudes and economic behavior. Journal of Economic Behavior and Organization, 148, 282300.

https://doi.org/10.1016/j.jebo.2018.02 .022

Kirchmaier, I., Prüfer, J., \& Trautmann, S. T. (2018b). Religion, Moral Attitudes and Economic Behavior. Journal of Economic Behavior \& Organization, 148 , 282-300. https://doi.org/https://doi.org/10.1016 j.jebo.2018.02.022

Mardani, D. A. (2019). Spritual
Entepreneurship Dalam Pemberdayaan Ekonomi Umat (Studi terhadap Tarekat Idrisiyah Pageningan Tasikmalaya). Al-Afkar, Journal For Islamic Studies, 4(1). https://doi.org/10.5281/zenodo.33420 71

Max Weber. (1958). Etika Protestan dan Semangat Kapitalisme (I). Pustaka Promethea.

Mudzakkir, A. (2017a). Konservatisme Islam dan Intoleransi Keagamaan di Tasikmalaya. Harmoni, 16(1), 57-74.

Mudzakkir, A. (2017b). Konservatisme Islam dan Intoleransi Keagamaan di Tasikmalaya. Jurnal Multikultural \& Multireligius, 16(1), 57-74.

Muhajir Salam. (2015). Koperasi dan Kerajinan Rakyat Tasikmalaya Pada Masa Kolonial. Historia Soekapoera, 2(1), 19. www.soekapura.com

Nadjib, M. (2013). Religion, Ethics And Work Ethos Of The Javanese Fishermen' S. Jurnal Ekonomi Pembanguan, 21(2), 137-150.

Nashihin, M. (2014). Analysis of Potential Demand for Microfinance Services in West-Java by District Areas. Procedia - Social and Behavioral Sciences, 115(Iicies 2013), 91-101. https://doi.org/10.1016/j.sbspro.2014. $\underline{02.418}$

Nusantara, D. dan I. P. P. di. (2019). Daftar Pondok Pesantren di Jawa Barat. https://ponpes.net/daftar-pondokpesantren-di-tasikmalaya/

Peraturan Daerah Kota Tasikmalaya Nomor: 12 Tentang Pembangunan Tata Nilai Kehidupan Kemasyarakayan yang Berlandaskan Pada Ajaran Agama Islam dan Norma Norma Sosial Masyarakat Kota Tasikmalaya, Pub. L. No. 12 Tahun 2009, 1 (2009). www.jdih.setjen.kemendagri.go.id

Permani, R. (2011). The presence of religious organisations, religious 
attendance and earnings: Evidence from Indonesia. Journal of SocioEconomics, 40(3), 247-258. https://doi.org/10.1016/j.socec.2011.0 1.006

Rokhman, W. (2010). The Effect of Islamic Work Ethics (IWE) on Work Outcomes. Electronic Journal of Business Ethics and Organization Studies, 15(1). https://doi.org/10.4103/18177417.104699

Yulianty, R. T., \& Octaviani, M. (2014).
Pengaruh Agama Dan Budaya Terhadap Etos Kerja Pebisnis Muslim Suku Bugis Di Kabupaten Nunukan Kalimantan Utara. Millah, i, 1-20.

Yulius, D. (2018). The Effect of Islamic Work Ethic and Motivation Through The Organizational Citizenship Behaviour and Employee Performance at Bank Aceh Syaria. Indian Journal of Public Health Research $\&$ http://repository.unimal.ac.id/4758/ 